\title{
Relationship between somatic cell counts and subclinical mastitis in lactating dairy cows
}

\author{
S. M. Mostafizur Rahaman Sumon ${ }^{1,2}$ D, Mst. Sonia Parvin ${ }^{1}$ (D) Md. Amimul Ehsan ${ }^{1}$ (D) and Md. Taohidul Islam ${ }^{1}$ (D) \\ 1. Population Medicine and AMR Laboratory, Department of Medicine, Faculty of Veterinary Science, Bangladesh \\ Agricultural University, Mymensingh 2202, Bangladesh; 2. Department of Medicine, Faculty of Veterinary Medicine and \\ Animal Science, Bangabandhu Sheikh Mujibur Rahman Agricultural University, Gazipur 1706, Bangladesh. \\ Corresponding author: Md. Taohidul Islam, e-mail: taohid@bau.edu.bd \\ Co-authors: SMMRS: mrsumon@bsmrau.edu.bd, MSP: soniaparvin@bau.edu.bd, MAE: amimul.med@bau.edu.bd \\ Received: 05-04-2020, Accepted: 02-07-2020, Published online: 27-08-2020
}

doi: www.doi.org/10.14202/vetworld.2020.1709-1713 How to cite this article: Sumon SMMR, Parvin MS, Ehsan MA, Islam MT (2020) Relationship between somatic cell counts and subclinical mastitis in lactating dairy cows, Veterinary World, 13(8): 1709-1713.

\begin{abstract}
Background and Aim: Subclinical mastitis (SCM) is one of the most prevalent diseases of dairy cows, and somatic cell count (SCC) is widely used to determine SCM and milk quality. However, setting the threshold of SCC is very important. This study aimed to determine the cow-level threshold of SCC to differentiate milk of SCM affected cows from normal milk in Bangladesh.
\end{abstract}

Materials and Methods: Sensitivity $(S e)$ and specificity $(S p)$ along with other characteristics of different thresholds of SCC were determined considering the bacterial culture as the gold standard test. Three definitions of intramammary infection (IMI) were set based on the group of pathogens involved. Five categories of SCC thresholds were considered for analysis.

Results: $S e$ and $S p$ of thresholds of SCC greatly varied as definitions of IMI changed. Irrespective of SCC thresholds, Se increased when isolation of major pathogens included in IMI definitions. Se decreased when SCC thresholds increased (from 100 to $300 \times 10^{3}$ cells $/ \mathrm{mL}$ ) for all IMI definitions and ranged from $60.6 \%$ to $20.3 \%$. The highest $S e$ was found at low SCC threshold $\left(100 \times 10^{3}\right.$ cells $\left./ \mathrm{mL}\right)$, which resulted in less false-negative outcome. On the other hand, $S p$ increased with the increment of SCC thresholds giving rise to a less false-positive outcome.

Conclusion: The cow-level SCC threshold of $100 \times 10^{3}$ cells $/ \mathrm{mL}$ was found appropriate to identify subclinical IMI of dairy cows.

Keywords: Bangladesh, bovine mastitis, intramammary infection, somatic cell count threshold, sensitivity, specificity.

\section{Introduction}

Mastitis is the most prevalent and important disease of dairy cows and responsible for the major economic losses to the dairy farms globally [1]. It is a multicausal disease, and various pathogens are involved in subclinical and clinical forms of mastitis $[2,3]$. Subclinical mastitis (SCM) is characterized by high somatic cell count (SCC) in milk without any visible abnormalities of the milk and udder and obvious systemic signs [3]. The occurrence of SCM is very common in dairy herds compared to clinical mastitis, which results in huge economic losses. It was estimated that decreased milk yield due to SCM caused losses of about 122.6 (US\$ 2.11) million Taka annually [4]. In addition, SCM affected cows remain as the source of infection to other cows in the herd.

SCM is most frequently the results of bacterial intramammary infection (IMI), therefore, the terms IMI and SCM are often used interchangeably [5]. The

Copyright: Sumon, et al. Open Access. This article is distributed under the terms of the Creative Commons Attribution 4.0 International License (http://creativecommons.org/licenses/ by/4.0/), which permits unrestricted use, distribution, and reproduction in any medium, provided you give appropriate credit to the original author(s) and the source, provide a link to the Creative Commons license, and indicate if changes were made. The Creative Commons Public Domain Dedication waiver (http:// creativecommons.org/publicdomain/zero/1.0/) applies to the data made available in this article, unless otherwise stated.
IMI is defined by the presence of any pathogens in the mammary quarter [6]. In general, IMI is predicted by the elevation of SCC, and also, the milk quality and mastitis control program are assessed based on SCC [7]. Somatic cells are mainly comprised of udder epithelial cells and white blood cells, that are, neutrophils, phagocytes, and lymphocytes, and can indicate IMI when elevated [8]. Consequently, it is essential to establish SCC threshold, which is a value that theoretically differentiates uninfected cows from the infected ones, and high-quality information is required on the operating characteristics (e.g., $S e$ and $S p$ ) to interpret the test results. SCM is often diagnosed on the basis of SCC values that exceed the threshold level. Several SCC cutoffs have been evaluated to distinguish between infected and non-infected mammary glands and to make management decisions. A mammary quarter is deemed to be healthy when the SCC level is usually lower than 100,000 cells/mL of milk $[9,10]$. Conceivably under field conditions, to reduce the diagnostic error, SCC below 200,000 cells/mL of milk is widely used as the threshold level to differentiate healthy udders from subclinically affected ones [11]. Some reports suggest that milk with high SCCs may not confirm the invasion of mammary quarter with mastitis pathogens in some cases, and conversely, it is also conceived that there is the presence of pathogens 
in milk with very low SCCs [11-13]. However, SCC is still of great value as a screening test to diagnose SCM provided the results are interpreted very carefully considering the demographic characteristics of cows.

Although the provision of SCC is readily available to most dairy farms in developed countries on a monthly basis through the dairy herd improvement (DHI) program, this practice yet not accustomed in Bangladesh. Because of the high prevalence (30-72\%) of SCM and abundance of the mastitis pathogens [14-19], the provision of SCCs for routine SCM screening in dairy herds will be of great benefit in reducing the occurrence of SCM and ensuring milk quality as well.

However, no precise and comprehensive reports are available on the $S e$ and $S p$ of SCC thresholds to determine SCM of dairy cows in Bangladesh. Considering this fact, this study aimed to determine the cow-level threshold of SCC for the diagnosis of SCM affected cows.

\section{Materials and Methods}

\section{Ethical approval and Informed consent}

There was no need for ethical approval as the study was carried out on milk of cows reared in different groups on the farm and generally fed with different locally available grasses and concentrates in different seasons. Moreover, the authors declare that they have obtained written informed consent from the owner of the animals to collect milk samples from cows along with data.

\section{Study period, selection of cows, collection and trans- portation of samples}

Ninety healthy cross-bred cows on lactation from Bangladesh Agricultural University Dairy Farm and smallholder dairy farms of Mymensingh Sadar Upazila were randomly selected, and subsequently, 360 mammary quarters were sampled aseptically for the collection of milk in Falcon tubes during the period from July 2016 to March 2017. The age, number of lactation, and lactation stage of cows were 2.5-8 years, 1-7, and 10-350 days, respectively. Before collection, cleaning followed by disinfection of the teat was done using $70 \%$ ethanol soaked cotton. Approximately $10 \mathrm{~mL}$ of milk sample was collected from each mammary quarter after discarding the first two to three streams of milk. Cows with visible abnormalities in the udder and milk, systemic signs of mastitis, and the history of any antimicrobial treatment during the past 7 days onward were excluded from the study. Moreover, cows at the $1^{\text {st }}$ week of lactation were not included because SCCs normally remain high in milk during this period.

\section{SCCs}

Somatic cells in milk samples were counted using NucleoCounter ${ }^{\circledR}$ SCC- $100^{\text {TM }}$ (ChemoMetec) as per the manufacturer's instruction. Briefly, equal volume of milk and reagent (50 $\mu \mathrm{L}$ each) were pre-diluted and then loaded in cassette and reading was taken.

\section{Isolation and identification of bacteria}

All the samples were examined bacteriologically as described earlier [20]. Briefly, within $24 \mathrm{~h}$ after collection, about $10 \mu \mathrm{L}$ of milk was inoculated onto $5 \%$ sheep blood agar plate in triplicate, then incubated aerobically for $48 \mathrm{~h}$. Positive culture was subcultured onto different selective media such as mannitol salt agar, MacConkey agar, EMB agar, cetrimide agar, and triple sugar iron slants. Bacteria were identified by means of colony morphology, Gram staining properties, hemolytic properties on blood agar, and properties of different biochemical reactions (e.g., catalase, coagulase, oxidase, methyl red/Voges-Proskauer, indole, and sugar fermentation) as described earlier [21]. Bacteria were grouped into three categories, (1) major pathogens that included Staphylococcus aureus, Escherichia coli, and Enterobacter spp., (2) minor pathogens, which consisted of coagulase-negative Staphylococcus, and (3) other pathogens that comprised Bacillus spp., Pseudomonas aeruginosa, and unidentified bacteria as reported earlier [19].

\section{IMI}

Three definitions of IMI were set based on the group of pathogens involved. Definition I: If there was a growth of any of the major pathogens, the quarter was considered infected; Definition II: If there was a growth of any of the major and/or minor pathogens; Definition III: If there was a growth of any major and/ or minor and/or other pathogens [22].

\section{Statistical analysis}

The validity of five various thresholds level of $\operatorname{SCC}\left(100,150,200,250\right.$, and $300 \times 10^{3}$ cells $\left./ \mathrm{mL}\right)$ was evaluated against bacterial culture for diagnosing IMI using the following quality parameters.

$\mathrm{Se}=\mathrm{TP} /(\mathrm{TP}+\mathrm{FN})$

$\mathrm{Sp}=\mathrm{TN} /(\mathrm{TN}+\mathrm{FP})$

$\mathrm{PPV}=\mathrm{TP} /(\mathrm{TP}+\mathrm{FP})$

$\mathrm{NPV}=\mathrm{TN} /(\mathrm{TN}+\mathrm{FN})$

Where,

$\mathrm{TP}=$ true-positive test result (infected quarter above SCC threshold)

$\mathrm{FP}=$ false-positive test result (uninfected quarter above SCC threshold)

$\mathrm{TN}=$ true-negative test result (uninfected quarter below or equal to SCC threshold)

$\mathrm{FN}=$ false-negative test result (infected quarter below or equal to SCC threshold)

Sensitivity $(\mathrm{Se})$ was the proportion of infected quarters that had SCC values above the selected threshold, and specificity $(S p)$ was the proportion of uninfected quarters that had SCC values below the selected threshold. Positive predictive value (PPV) was the proportion of truly infected quarters to the test positive quarters and negative predictive value (NPV) was the proportion of truly uninfected quarters to the test negative quarters. Descriptive statistics such as frequency and confidence intervals were performed using the statistical software SPSS v.22. 


\section{Results}

The bacteriological analysis revealed that $35.6 \%$ of samples were culture positive; that is, the quarter-level prevalence of IMI was $35.6 \%$. However, no growth was observed in $64.4 \%$ of samples. Major pathogens were isolated from $32.8 \%$ of samples while minor pathogens from $17.2 \%$ of samples. Se, Sp, and predictive values at different levels of SCC thresholds are presented in Table-1.

$\mathrm{Se}$ was decreased (60.6-20.3\%) with the increase of SCC thresholds for all IMI definitions. However, there was an increase in Se for all SCC threshold levels when IMI definition was restricted only to the presence of major pathogens. For an SCC threshold of $100 \times 10^{3}$ cells $/ \mathrm{mL}$ of milk, Se was $60.6 \%$ versus $53.1 \%$ (IMI Definition I vs. III), and for threshold of $200 \times 10^{3}$ cells $/ \mathrm{mL}$, Se was $36.4 \%$ versus $29.7 \%$ (IMI Definition I vs. III).

In this study, $S p$ ranged from 87.1 to $97.4 \%$ for different SCC thresholds and IMI definitions. There was an increase in $S p$ when culture-negative results were interpreted as the absence of IMI at all SCC threshold levels. At SCC thresholds of $100 \times 10^{3}$ cells $/ \mathrm{mL}$ and $200 \times 10^{3}$ cells $/ \mathrm{mL}, S p$ values were $95.7 \%$ and $96.6 \%$, respectively, when uninfected mammary quarters were defined on the basis of culture-negative results only. However, the $\mathrm{Se}$ was high at low SCC threshold (i.e., $100 \times 10^{3}$ cells $/ \mathrm{mL}$ ), which resulted in less false-negative outcome. On the contrary, $S p$ was increased with the increment of SCC thresholds, which resulted in least false-positive outcome. PPVs and NPV ranged from $43.8 \%$ to $87.2 \%$ and $68.9-90.8 \%$, respectively, depending on SCC thresholds and IMI definitions.

\section{Discussion}

This is the first report on SCC threshold at cow-level for the diagnosis of SCM of dairy cows in Bangladesh where mastitis pathogens are abundant. As SCM is most often due to bacterial IMI [5], we calculated the SCC thresholds taking the IMI as the gold standard test. The results can be extrapolated in other developing countries where dairy farming system and abundance of mastitis pathogens are as alike as Bangladesh. As errors may arise in any diagnostic test, particularly when reliance is placed on a single screening profile [23], we calculated $S e$ and $S p$ at five levels of SCC thresholds here in this study.

The results of this study indicated that $\mathrm{Se}$ was decreased with the increment of SCC thresholds for all IMI definitions. However, $\mathrm{Se}$ values increased at all SCC thresholds when IMI definition was restricted to only major pathogens. It might be due to the inclusion of all types of pathogens (minor and other pathogens in addition to major pathogens) in IMI definition that might have resulted in false-negative outcome as minor and other pathogens seldom cause severe mammary inflammation other major pathogens [12]. This result is in agreement with the earlier report in which $\mathrm{Se}$ at SCC threshold of $100 \times 10^{3}$ cells $/ \mathrm{mL}$ was the highest $(74.0 \%)$ when only major pathogens were associated with IMI and lowest (66.4\%) when both the

Table-1: Sensitivity, specificity, and predictive values (positive and negative) of five SCC thresholds $\left(100-300 \times 10^{3}\right.$ cells $\left./ \mathrm{mL}\right)$ to identify IMI, considering three criteria of IMI of dairy cows.

\begin{tabular}{|c|c|c|c|c|}
\hline \multirow{2}{*}{$\begin{array}{l}\text { Criteria and SCC } \\
\text { threshold }\end{array}$} & \multirow{2}{*}{$\begin{array}{l}\text { Sensitivity, \% } \\
\text { (95\% CI) }\end{array}$} & \multirow{2}{*}{$\begin{array}{l}\text { Specificity, \% } \\
\text { (95\% CI) }\end{array}$} & \multicolumn{2}{|c|}{ Predictive value $^{1}, \%(95 \% \mathrm{CI})$} \\
\hline & & & PPV & NPV \\
\hline \multicolumn{5}{|c|}{ IMI = only major pathogens; $\mathrm{UMQ}^{2}=$ only culture-negative samples } \\
\hline $100 \times 10^{3}$ & $60.6(54.8,66.4)$ & $95.7(95.2,96.2)$ & $80.0(75.6,84.4)$ & $89.5(88.3,90.7)$ \\
\hline $150 \times 10^{3}$ & $48.5(42.5,54.5)$ & $96.6(96.2,97.0)$ & $80.0(75.0,84.9)$ & $86.8(85.4,88.2)$ \\
\hline $200 \times 10^{3}$ & $36.4(30.8,41.9)$ & $96.6(96.2,97.0)$ & $75.0(68.5,81.5)$ & $84.2(82.6,85.8)$ \\
\hline $250 \times 10^{3}$ & $27.3(22.5,32.1)$ & $97.4(97.1,97.7)$ & $75.0(67.5,82.5)$ & $82.5(80.8,84.2)$ \\
\hline $300 \times 10^{3}$ & $21.2(17.2,25.2)$ & $97.4(97.1,97.7)$ & $70.0(60.8,79.2)$ & $81.3(79.5,83.1)$ \\
\hline \multicolumn{5}{|c|}{ IMI = only major pathogens; UMQ = minor pathogen, others and culture-negative samples } \\
\hline $100 \times 10^{3}$ & $60.6(54.8,66.4)$ & $87.1(85.8,88.4)$ & $51.3(45.8,56.8)$ & $90.8(89.8,91.8)$ \\
\hline $150 \times 10^{3}$ & $48.5(42.5,54.5)$ & $91.8(90.9,92.7)$ & $57.1(50.7,63.5)$ & $88.8(87.7,89.9)$ \\
\hline $200 \times 10^{3}$ & $36.4(30.8,41.9)$ & $92.5(91.7,93.3)$ & $52.2(44.9,59.4)$ & $86.6(85.3,87.8)$ \\
\hline $250 \times 10^{3}$ & $27.3(22.5,32.1)$ & $93.2(92.5,93.9)$ & $47.4(39.5,55.3)$ & $85.1(83.7,86.5)$ \\
\hline $300 \times 10^{3}$ & $21.2(17.2,25.2)$ & $93.9(93.2,94.6)$ & $43.8(35.3,52.3)$ & $84.1(82.7,85.5)$ \\
\hline \multicolumn{5}{|c|}{$\mathrm{IMI}=$ major and minor pathogens; $\mathrm{UMQ}=$ only culture-negative samples } \\
\hline $100 \times 10^{3}$ & $56.8(51.7,61.9)$ & $95.7(95.2,96.2)$ & $83.3(79.8,86.8)$ & $85.4(83.9,86.9)$ \\
\hline $150 \times 10^{3}$ & $40.9(35.8,45.9)$ & $96.6(96.2,97.0)$ & $81.8(77.4,86.2)$ & $81.2(79.4,83.0)$ \\
\hline $200 \times 10^{3}$ & $31.8(27.3,36.3)$ & $96.6(96.2,97.0)$ & $77.8(72.2,83.4)$ & $78.9(76.9,80.8)$ \\
\hline $250 \times 10^{3}$ & $25.0(21.1,28.9)$ & $97.4(97.1,97.7)$ & $78.6(72.4,84.8)$ & $77.4(75.4,79.4)$ \\
\hline $300 \times 10^{3}$ & $20.5(17.1,23.9)$ & $97.4(97.1,97.7)$ & $75.0(67.5,82.5)$ & $76.4(74.3,78.5)$ \\
\hline \multicolumn{5}{|c|}{ IMI = major, minor, and other pathogens; UMQ = only culture-negative samples } \\
\hline $100 \times 10^{3}$ & $53.1(48.8,57.4)$ & $95.7(95.2,96.2)$ & $87.2(84.7,89.7)$ & $78.7(76.7,80.7)$ \\
\hline $150 \times 10^{3}$ & $37.5(33.4,41.6)$ & $96.6(96.2,97.0)$ & $85.7(82.5,88.9)$ & $73.7(71.5,75.9)$ \\
\hline $200 \times 10^{3}$ & $29.7(26.1,33.3)$ & $96.6(96.2,97.0)$ & $82.6(78.4,86.8)$ & $71.3(69.0,73.6)$ \\
\hline $250 \times 10^{3}$ & $25.0(21.8,28.2)$ & $97.4(97.1,97.7)$ & $84.2(79.9,88.4)$ & $70.2(67.9,72.5)$ \\
\hline $300 \times 10^{3}$ & $20.3(17.5,23.1)$ & $97.4(97.1,97.7)$ & $81.3(75.9,86.5)$ & $68.9(66.6,71.2)$ \\
\hline
\end{tabular}

${ }^{1} \mathrm{PPV}=$ Positive predictive value, $\mathrm{NPV}=$ Negative predictive value, ${ }^{2} \mathrm{UMQ}=$ Uninfected mammary quarters, $\mathrm{CI}=$ Confidence interval 
major and minor pathogens were taken into account as the causes of IMI [24].

$S p$ increased with the increase of SCC thresholds for all IMI definitions. This results well correspond with the earlier observation in which $S p$ values were increased from 50.8 to $81.2 \%$ with the increase of SCC thresholds and for different IMI definitions [24]. Both $S e$ and $S p$ were considerably higher for distinguishing IMI with major pathogens from other pathogens, which is compatible with previous reports [25].

Both PPV and NPV ranged from 43.8 to $87.2 \%$ and 68.9 to $90.8 \%$, respectively, depending on SCC thresholds and IMI definitions. The findings of high PPV may possibly be due to the high prevalence of IMI with major pathogens. Besides, the culture results of either pooled, single, duplicate, or triplicate milk samples to define IMI may also influence the predictive values as described earlier [22,26].

High $\mathrm{Se}$ at low SCC thresholds and increased $S p$ with the increase of SCC thresholds found in our study are consistent with earlier observations [27]. We found maximum $S e$ and minimum $S p$ at SCC threshold of $100 \times 10^{3}$ cells $/ \mathrm{mL}$ and for all IMI definitions. It is likely that use of SCC threshold value of $200 \times 10^{3}$ cells $/ \mathrm{mL}$ instead of threshold of $100 \times 10^{3}$ cells $/ \mathrm{mL}$ might account higher occurrence of false-negative outcome, that is, some truly infected cows with low SCC could be identified as non-infected. The occurrence of such false-negative results may adversely affect the implementation of a mastitis control program in farms because some cows could not be correctly identified as a source of infection. Thus, based on the findings, it was evident that the SCC threshold level of $100 \times 10^{3}$ cells $/ \mathrm{mL}$ could be considered to detect the subclinically infected mammary quarters and to lessen the possibility of false-negative outcome. The results are consistent with the earlier recommendation [24]. Other researchers also proposed the threshold level of $100 \times 10^{3}$ cells $/ \mathrm{mL}[22,25]$.

Although in detecting IMI, culture of bacteria is deemed a reliable process, isolation of pathogens may be affected by various factors such as type of bacteria, amounts of bacteria in milk along with intermittent excretion nature, frequency of sampling, storage condition of sample, volume of milk plated, and presence of some enzymes/proteins [22,28]. In this context, bacterial culture in triplicate could be ideal for detecting IMI but not cost-effective [29]. In an attempt to minimize the cost, culture of single milk sample could also be worthwhile for the detection of IMI. Reports also suggest that the culture of a single milk sample is allowable to determine IMI caused by most of the mastitic pathogens since the $S e$ and $S p$ were quite higher $(85.8 \%$ and $75.1 \%)$ in comparison to the culture results of milk in triplicate [22]. Therefore, the cow-level SCC threshold determined in our study based on single milk sampling would be applicable for all tropical countries as like as Bangladesh.

\section{Conclusion}

$\mathrm{Se}$ is increased when the threshold level of SCC is lowered, and $S p$ increased when the threshold is raised. However, increased $S e$ results in less false-negative outcome while increased $S p$ gives minimal false-positive outcome. Based on the findings, the cow-level SCC threshold of $100 \times 10^{3}$ cells $/ \mathrm{mL}$ that results in less false-negative outcome could be appropriate to identify the IMI of lactating dairy cows in countries like Bangladesh where mastitis pathogens are abundant.

\section{Authors' Contributions}

SMMRS was involved in designing and conducting the study, analyzing data, and drafting the manuscript. MSP contributed to conducting the study, analyzing data, and revising the manuscript. MAE contributed to the study design and revision of the manuscript. MTI was involved in conceptualizing, supervising, designing, and coordinating the study, interpreting data, and revising the manuscript.

\section{Acknowledgments}

The authors acknowledge partial financial support in the form of a research fellowship from the Ministry of Science and Technology, Govt. of the People's Republic of Bangladesh (Fellowship No. 39.012.002.01.03.019.2013-283).

\section{Competing Interests}

The authors declare that they have no competing interests.

\section{Publisher's Note}

Veterinary World remains neutral with regard to jurisdictional claims in published institutional affiliation.

\section{References}

1. Ruegg, P.L. (2017) A 100-year review: Mastitis detection, management, and prevention. J. Dairy Sci., 100(12): 10381-10397.

2. Kibebew, K. (2017) Bovine mastitis: A review of causes and epidemiological point of view. $J B A H, 7(2): 1-14$

3. Kumari, T., Bhakat, C. and Choudhary, R. (2018) A review on subclinical mastitis in dairy cattle. Int. J. Pure Appl. Biosci., 6(2): 1291-1299.

4. Kader, M., Samad, M. and Saha, S. (2003) Influence of host level factors on prevalence and economics of subclinical mastitis in dairy milch cows in Bangladesh. Indian J. Dairy Sci., 56: 235-240.

5. Deluyker, H., Van Oye, S. and Boucher, J. (2005) Factors affecting cure and somatic cell count after pirlimycin treatment of subclinical mastitis in lactating cows. J. Dairy Sci., 88(2): 604-614.

6. Bradley, A.J., De Vliegher, S., Green, M.J., Larrosa, P., Payne, B., van de Leemput, E.S., Samson, O., Valckenier, D., Van Werven, T. and Waldeck, H. (2015) An investigation of the dynamics of intramammary infections acquired during the dry period on European dairy farms. J. Dairy Sci., 98(9): 6029-6047.

7. Sharma, N., Singh, N. and Bhadwal, M. (2011) Relationship of somatic cell count and mastitis: An overview. Asian Aust. J. Anim. Sci., 24(3): 429-438. 
8. Alhussien, M.N. and Dang, A.K. (2018) Milk somatic cells, factors influencing their release, future prospects, and practical utility in dairy animals: An overview. Vet. World, 11(5): 562.

9. Hamann, J. (2005) Diagnosis of mastitis and indicators of milk quality. In: Mastitis in Dairy Production: Current Knowledge and Future Solutions. Wageningen Academic Publishers, Portland, OR, Hogeveen. p82-90.

10. Leitner, G., Eligulashvily, R., Krifucks, O., Perl, S. and Saran, A. (2003) Immune cell differentiation in mammary gland tissues and milk of cows chronically infected with Staphylococcus aureus. J. Vet. Med. B, 50(1): 45-52.

11. Petzer, I.M., Karzis, J., Donkin, E.F., Webb, E.C. and Etter, E. (2017) Somatic cell count thresholds in composite and quarter milk samples as indicator of bovine intramammary infection status. Onderstepoort J. Vet. Res., 84(1): 1-10.

12. Oliveira, L., Hulland, C. and Ruegg, P. (2013) Characterization of clinical mastitis occurring in cows on 50 large dairy herds in Wisconsin. J. Dairy Sci., 96(12): 7538-7549.

13. Alekish, M. (2015) The association between the somatic cell count and isolated microorganisms during subclinical mastitis in heifers in Jordan. Vet. Med. Czech, 60(2): 71-76.

14. Sarker, S.C., Parvin, M.S., Rahman, A.A. and Islam, M.T. (2013) Prevalence and risk factors of subclinical mastitis in lactating dairy cows in North and South regions of Bangladesh. Trop. Anim. Health Prod., 45(5): 1171-1176.

15. Badiuzzaman, M., Samad, M., Siddiki, S., Islam, M. and Saha, S. (2015) Subclinical mastitis in lactating cows: Comparison of four screening tests and effect of animal factors on its occurrence. Bangladesh J. Vet. Med., 13(2): 41-50.

16. Hoque, M.N., Das, Z.C., Talukder, A.K., Alam, M.S. and Rahman, A.N.M. (2015) Different screening tests and milk somatic cell count for the prevalence of subclinical bovine mastitis in Bangladesh. Trop. Anim. Health Prod., 47(1): 79-86.

17. Kabir, M.H., Ershaduzzaman, M., Giasuddin, M., Nazir, K.N.H., Mahmud, M.M., Islam, M.R., Islam, M.S., Karim, M.R., Yousuf, M.A. and Rahman, S.M. (2017) Prevalence and molecular detection of the causal agents of sub-clinical mastitis in dairy cows in Sirajganj and Pabna districts, Bangladesh. J. Adv. Vet. Anim. Res., 4(4): 378-384.

18. Sumon, S.M.M., Haider, M.G., Islam, M.A., Siddiki, S.H.M. and Karim, M.R. (2018) Prevalence and antibiogram profile of Staphylococcus aureus isolated from milk samples of lactating cows with subclinical mastitis in Gazipur, Bangladesh. Ann. Bangladesh Agric., 22(1): 51-60.

19. Sumon, S.M.M., Ehsan, M.A. and Islam, M.T. (2017) Subclinical mastitis in dairy cows: Somatic cell counts and associated bacteria in Mymensingh, Bangladesh. $J$. Bangladesh Agril. Univ., 15(2): 266-271.

20. Adkins, P.R. and Middleton, J.R. (2017) Laboratory Handbook on Bovine Mastitis. National Mastitis Council, Inc., Madison, WI.

21. Quinn, P.J., Markey, B.K., Leonard, F., FitzPatrick, E. and Fanning, S. (2015) Concise Review of Veterinary Microbiology. John Wiley \& Sons, United States.

22. Dohoo, I., Smith, J., Andersen, S., Kelton, D. and Godden, S. (2011) Diagnosing intramammary infections: Evaluation of definitions based on a single milk sample. J. Dairy Sci., 94(1): 250-261.

23. Schukken, Y.H., Wilson, D.J., Welcome, F., GarrisonTikofsky, L. and Gonzalez, R.N. (2003) Monitoring udder health and milk quality using somatic cell counts. Vet. Res., 34(5): 579-596.

24. Dos Reis, C.M., Barreiro, J., Moreno, J., Porcionato, M. and Santos, M. (2011) Evaluation of somatic cell count thresholds to detect subclinical mastitis in Gyr cows. J. Dairy Sci., 94(9): 4406-4412.

25. Sargeant, J., Leslie, K., Shirley, J., Pulkrabek, B. and Lim, G. (2001) Sensitivity and specificity of somatic cell count and California mastitis test for identifying intramammary infection in early lactation. J. Dairy Sci., 84(9): 2018-2024.

26. Reyher, K. and Dohoo, I. (2011) Diagnosing intramammary infections: Evaluation of composite milk samples to detect intramammary infections. J. Dairy Sci., 94(7): 3387-3396.

27. Dohoo, I.R., Martin, W. and Stryhn, H. (2003) Veterinary Epidemiologic Research. AVC Incorporated Charlottetown, Canada.

28. Souza, F.N., Cunha, A.F., Rosa, D.L., Brito, M.A.V., Guimarães, A.S., Mendonça, L.C., Souza, G.N., Lage, A.P., Blagitz, M.G. and Della Libera, A.M. (2016) Somatic cell count and mastitis pathogen detection in composite and single or duplicate quarter milk samples. Pesqui. Vet. Bras., 36(9): 811-818.

29. Andersen, S., Dohoo, I., Riekerink, R.O. and Stryhn, H. (2010) Diagnosing intramammary infections: Evaluating expert opinions on the definition of intramammary infection using conjoint analysis. J. Dairy Sci., 93(7): 2966-2975.

\section{$* * * * * * * *$}

